Ditride into ammonis by the addition of alkali and also to diotioguish the erystals of the nitride under the microscope. Weston and Ellis 1 have studied this reaction and have obtained up to 40 per cent. of tho nitride in this way.

Aluminium nitrido as prepared by Serpelk is of value not only from its combined nitrogen but also from the valuable by-product of alumina arising from its decomposition. This should be available for the manufacture of cluminium. Without this advantege the process as one for the fixation of nitrogen would be of doubtful value; the alumina would have to be used over again as raw material after evolving the ammonia, and apart from the complica. tions, alumina in the pure state requirea a much higher temperature for nitrogen fixation than bauxite. So much so is this the case that if this were done it is very doubtful if the process could be carried on successfully.

In a recent paper 14 I have attempted to show how much this production of alumina is concerned with the aluminium indust ry. If the Serpel process wero to be worked on acale commensursto with tho Frank cyansmide process, the production of aluminu would actually exceed the present demands of the aluminium industry in raw meterial to the extent of some 34,000 tons annually. However, there scems little doubt that the Serpek alumina would find a ready market. It is quite impossible to compare the cost of producing fixed nitrogen by the Frank and Serpek prooesses, because wo know very littlo as to the costs of making oyanamido by tho former, and still less as to the cost of the Berpek product. Perhaps the best way of comparing the processes is to contrast the chief points of each, as follows:-

\section{Frank Process.}

\begin{tabular}{|c|c|}
\hline $\begin{array}{l}\text { Parourable. } \\
\text { Low power conts for nitrogen } \\
\text { Axed. } \\
\text { noteriil can be used directly } \\
\text { ax fertiliser. }\end{array}$ & $\begin{array}{l}\text { Vufarourable. } \\
\text { Process discontlinuouus. } \\
\text { Heat losses at carbldo manufacture } \\
\text { stage. } \\
\text { Expentive nitrogen. } \\
\text { Two rather complicated grinding }\end{array}$ \\
\hline & $\begin{array}{l}\text { operations. } \\
\text { product. }\end{array}$ \\
\hline
\end{tabular}

Serpel Irocess.

\section{Parourable.}

Continuous proceas. duct.

Iient conerved.

Valuable by product.

From thig it would seem that there were decided advan. tages attached to the Serpek process, but it remains to be seen just how it will work in practice. It is now being tried in France on a largo experimental scale.

\section{New York Section.}

\section{Yeeting held at Chemisls' Building on Friday, November 21st,} 1913.

zR. O. W. THOMPSON IX THE cham.

\section{THE RELATION OF COMPOSITION OF ASH IN COAL TO ITS FUSION TEMPERATURE.}

\section{by oscan W. Palyenbeag, D.g.}

One of the moet troublesomo features in the combustion of conl is that due to the production of ulinker, whioh influences the rate of combustion and the cost of mainten. ance, especially where automatio stokers aro in use. A coal may olinker so readily as to bo unfit for use, isrespective of its fuol valuo. When conl is burned under - boilor for the production of steam, it is especially

is Weston and Zills, Tran. Faraday Boc., 4, 60, 1608. 14 Tucker, The relation of aluming to the txatlon of nitrocen,
Joue. Ind. and Bng. Chom., 101 (1018). important to know whrther the ash will clinker and at. what temperat ure.

Several mothods have been suggested to determine whether a coal has an ash which will fuso at a low temperature, and many persons havo held that an analysis of the ash or the amount of iron in tho ash, or of sulphur in the cosl will give the explanation.

To show that there is no relation betwcen the olinkoring quality of a coal and the sulphur or iren content, the writer hag marde this investigation, and the analyses of the ash together with the fusing temperature determinations on a wide rango of conls will readily show that no conclusion can be obtained from a chomical analyais.

Tho ash of coal is composed mainly of silica, iron oxido, aluminium oxide, calcium oxide, magnesjum oxido, sodium oxide, potassium oxide, carbonates and sulphites. Bince all cosls, but particularly soft conly, consist of a mixture of pure conl substanco and pyrites, bonc, klate, fire-clay, otc., thoso elements will be present in a varisble proportion deponding upon the nature of the coal vein and the method and caro by which the coal is oxtracted from tho ground. In making an analysis, tharefore, of a col sample repro. senting a mixture of all theso materials, a definite percontage of the component parts of the ash may be obtained, but this anslysis does not tell us how much pyrites, bone, slato, firc.clay, otc., is present. It is, therefore, apparently impossiblo to judgo from this analysis whother the ash will beve a high or low fusing tomperaturo. It is true that tho pyrito will fuse at a lower temperature than the slate, but sinco both may contain iron, the analysis does not indicate a method of arriving at a conclusion to show the Iusibility of the ash due $t$, tho iron content. The problem offered is very similar to that of trying to determino a formula by which the calorific value of a coal may be ostimated. This has been attompted by using tho porcentago of ash and volatilo matter or of ash and fixed carbon but since those constituents are so varinble in their composition, dopending upon their sources, it is impossible to arrive at a reliable mothod. For that reason a calorimetrio dotermination must bo mado.

The following analyses and fusing temperature doterminations were made on coals minod in Pennsylvanis and samples were obtained cither from the mine or place of consumption :-

Fuoing temperature of the ash in coal arranged according to the iron content.

\begin{tabular}{|c|c|c|c|c|}
\hline No. & $\mathrm{Fe}_{y_{0}} \mathrm{O}_{2}$ & $\begin{array}{r}\mathbf{S} \\
\%\end{array}$ & $\underset{w}{A s h}$. & Fus. $\mathrm{T}$. \\
\hline $\begin{array}{l}1 \\
\mathbf{3} \\
\mathbf{3} \\
4 \\
5 \\
6 \\
7 \\
8 \\
9 \\
10 \\
11 \\
12 \\
13 \\
14 \\
15 \\
16 \\
17 \\
18 \\
10 \\
20 \\
21 \\
22 \\
23 \\
24 \\
25 \\
26 \\
27 \\
28 \\
20 \\
30 \\
91 \\
92 \\
39 \\
94 \\
35 \\
30 \\
97 \\
98\end{array}$ & 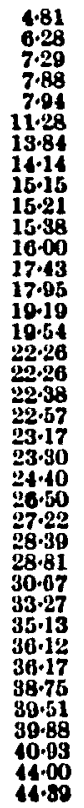 & 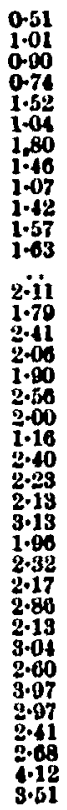 & 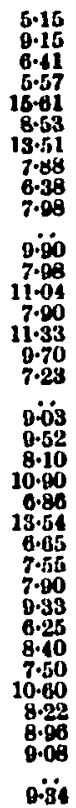 & 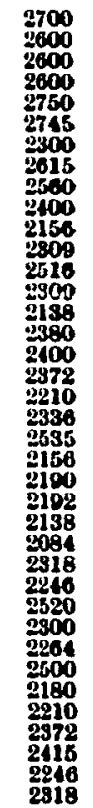 \\
\hline
\end{tabular}




\begin{tabular}{|c|c|c|c|c|c|c|c|c|c|}
\hline No. & Fus. Cemp. & $\mathrm{Fe}_{2} \mathrm{O}_{2}$ & Bulphur. & $\mathrm{SiO}_{3}^{*}$ & $\mathrm{Al}_{\mathbf{3}} \mathrm{O}_{2}$ & CaO & HgO & $\underset{\mathrm{N}}{\mathrm{K}_{2} \mathrm{O}, \mathrm{OO}, \mathrm{CO}}$ & Ash. \\
\hline $\begin{array}{r}1 \\
2 \\
3 \\
4 \\
5 \\
5 \\
6 \\
7 \\
8 \\
9 \\
10 \\
11\end{array}$ & $\begin{array}{r}{ }^{\circ} \mathrm{C} . \\
\mathbf{2 7 0 0} \\
2615 \\
2000 \\
2400 \\
\mathbf{2 4 0 0} \\
\mathbf{2 3 7 2} \\
\mathbf{9 3 0 0} \\
\mathbf{9 3 0 0} \\
\mathbf{9 0 0} \\
2940 \\
\mathbf{2 1 8 0}\end{array}$ & 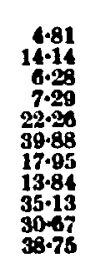 & $\begin{array}{l}0.51 \\
1.46 \\
1.01 \\
0.00 \\
2.00 \\
2.41 \\
2.11 \\
1.80 \\
2.13 \\
2.17 \\
3.97\end{array}$ & 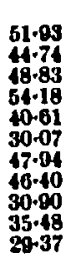 & $\begin{array}{l}\mathbf{3 6} \cdot 82 \\
36 \cdot 91 \\
42 \cdot 62 \\
34 \cdot 53 \\
32-94 \\
25.31 \\
98.47 \\
35 \cdot 30 \\
31 \cdot 14 \\
30 \cdot 73 \\
20 \cdot 52\end{array}$ & $\begin{array}{l}3.84 \\
2 \cdot 18 \\
1.61 \\
3.01 \\
1.77 \\
2.63 \\
4 \cdot 17 \\
3.58 \\
2.00 \\
2.10 \\
1.57\end{array}$ & $\begin{array}{l}1.00 \\
0.41 \\
0.30 \\
0.47 \\
0.51 \\
0.39 \\
0.51 \\
0.31 \\
0.52 \\
0.44 \\
0.37\end{array}$ & $\begin{array}{l}1.60 \\
4.85 \\
8.90 \\
0.52 \\
1.91 \\
1.71 \\
0.96 \\
0.37 \\
0.31 \\
0.28 \\
0.44\end{array}$ & $\begin{array}{r}5 \cdot 15 \\
7 \cdot 88 \\
9.15 \\
6 \cdot 11 \\
9 \cdot 70 \\
8 \cdot 96 \\
11.04 \\
13.61 \\
6.25 \\
7.90 \\
10.60\end{array}$ \\
\hline
\end{tabular}

Thase analyses seem to show that there is no relation between the porcentages of the various constituents of tho ash and tho fusing tomperature. Thereforo a chemical analysis is of no value to arrive at a conglusion regarding tho clinkering quality of a coal. It mny be notod that, although c sals having an ash with very low iron content scem to givo tho highest fusing $a s h$, no dofinite fusing tomporature fits a definite percentage, and when the iron content goes beyond 10 por cent. the fusion temperature cannot be judged at all. That tho sulphur content of the cosl has no bearing whatsoover upon the fusibility of the ash is also npperent.

Tho writer interide to continue this investigation on cosls from other couroes than Ponncylvani with the object of dotermining whother there may not bo somo having prootically no iron and showing a low fusing ash.

Since the oulphur occurs in coal combined either with iron, limo, or the hydrocarbons, there naturally exist innumernble combinstions, and for this reason the sulphur content cannot be uned as an index to olinkering. Only in thowe cases in whioh the sulphur is in combinntion with the iron, in the form of pyrites, would it bo possible to judge the clinkering property, if the iron content of the an had any bearing upon the fusion temperature.

The fusion temperature dotermination of the ash of cosl will in the future displace the sulphur dotermination in cosle used for stes ming purposes, and will rendily show tho fallacy of buying and selling coal on an analysis basis whore specifications ore uecd containing sulphur tobles penelising boyond s certain gunranteed amount of sulphur. It has boen quite a common praotice to place 1.50 per cent sulphur as a limit and penulising as much as 4 conts per ton for overy 0.25 per cent. above 1.50 per cont. The injustice of this practice is vory ovident, as it often happens that coals with a high sulphur content are extremoly high in heat valuo and do not clinker readily at all. Sineo tho sulphur has no appreciable eficet upon tho motallio parts of tho furnace it noed thorvfore not be considered in the selection of a cosl for stesming purposes.

To arrive at the value of a cosl for steaming purposes it is therefore juat \& essential to make the fusion test of the ash $a s$ it is to make the calorimetric determination. If these detorminations aro made there is a ready explanstion why two cosls of apperently like pmximate analyses give entirely difierent evaporation when fired under like oonditions.

\section{Drsaussion.}

Mr. J. B. F. HenResmomr asid that tho practioal results of coal users seomed at variance with tho conolusions of Mr. Palmenberg. In tho exporiments of his own company, it had beon found that when the ash contained less than 8 por cont. of iron, the amount of olinkering was tolorable, but that when tho amount of iron was as high as 15 por cont. of the ash, tho olinkoring was so marked that.thoy could not uso the coal, whilo with 30 por cent. of iron in tho ash, the ash was so fusible that it would drip through tho grate bars. Coal with not moro than 10 por cent. of ash, and of whioh ash 8 to 8 yer oont. might bo iron, was found to bo satisfactory. With coal high in fixod carbon there was more olinkoring than in the oaso of cosls low in fixed oarbon on account of tho highor tomporaturo to which tho ash was subjooted during combustion in tho former case. The great difficulty that his company had exporienced with coal analyses was that of sampling.

Mr. Fuxrst asked if from these analyses, calculation. had been made upon the probable fusibility of the $a a^{2}$ in the manner understood by metallurgist $s$ in the calculation of blast furnace slags.

Mr. G. W. Thoyrsos asked if in the tests to determine the fusing point of the ash, the coal had been completely burned before making the melting test, or if some carbon had been left associnted with it, and upon Mr. Palmenberg's reply that the ash was tested after complete burning 80 that the ash was thoroughly oxidised and free from any contamination with carbon, he suggested that the dis. crepancies between Mr. Palmenberg's nesults and thoso found by Mr. Herreshoff in sotual practice might be accounted for by supposing that in the laboratory tests of Mr. Palmenberg the iron in the ash was in the ferrio condition whilo in actual practice the iron would bo in the ferrous condition at the time it was subjected to the heat which produced clinkering, ferrous iron being a fluxing ingredient though forric iron might not be.

Mr. P. B. HyDz asked what the effect of limo in the ash might be ; in his experience a clay containing 5 per cent. of lime would bo much mone fusiljle than the same clay without it.

In answer to Mr. Herieshof, Mr. Palymibero said that he had found many conls running higher than 15 per cent. that would not clinker readily, and those showing the higher fusion test would give splendid results under actual firing conditions. The clinkering of 8 cosl in a furnace depended upon the rate of combustion, and if the nature of the oal was suoh that it generated a higher temperatur than the fusion temperature of the ash, then clinker would be formed if the ash were in sufficient quantity and exposed to tho hot fire-bed. Ho presumed that the ooals that Mr. Herreshoff referred to were burned under oonditions that the rate of combustion would give a very high furnaco temperature.

In answer to Mr. Hydo's question, lime in appreciable quantity would no doubt influence the fusion temperature as it would flux with the silics. The cosls investigated had all been low in lime and, therefore, no conolusion eould bo obtained in regard to its influenco. The aralyses bore out the fart that the fusion temperature was not influonoed by the small amount of lime present, and should the limo reduce the fusion temperature, the effect might be offset by tho presenoe of a larger amount of alumina whioh had the property of making tho ash infusible.

\section{Scottish Section.}

Meeting held at Olasgow on Tuesday, November $25 t h, 1913$. DR. THOMAS EWAN IN THE CHALR.

\section{A NEW FORM OF EXTRACTION APPARATUS AND REFLUX CONDENSER.}

BY PROBODHa CHUXDRA CLATTOPADHYAY, Y.A.

\section{(A) Extraction Apparatus.}

Aftor working with various forms of extraotion apparatu, tho writer has tried to reotify somo of thoir 